\title{
A high local species richness and biodiversity within high-latitude calcareous aggregates of tube-building polychaetes
}

\author{
Hallvard Haanes • Bjørn Gulliksen
}

Received: 11 August 2010/Accepted: 23 December 2010/Published online: 7 January 2011

(C) The Author(s) 2011. This article is published with open access at Springerlink.com

\begin{abstract}
In general, biodiversity and species richness follow the latitudinal diversity gradient and decrease from the tropics towards the poles. Exceptions have however been recorded, as for deep coldwater coral reefs at high latitudes, which comprise biodiversity hotspots. Here we assess and characterise the high-latitude $\left(69^{\circ} \mathrm{N}\right)$ species richness and diversity of a local shallow-water fauna associated with small calcareous aggregations of a serpulid polychaete. A dense and very species rich fauna was recorded within aggregations of Filograna implexa Berkeley, 1828. Totally 4663 individuals belonging to 99 species (61 solitary, 38 colonial) were recorded in a total aggregation volume of only 4.41 covering an area less than $0.05 \mathrm{~m}^{2}$ of a wreck situated in a tidal stream in North Norway. The number of species within each aggregation was positively related to its size, indicating that the high species diversity may be due to structural heterogeneity, which increase with aggregation size and probably creates new microhabitats and protect against predation. We present a species list including abundance and biomass, pin-point common species and describe a method for sampling such faunas associated with calcareous structures.
\end{abstract}

Keywords Diversity $\cdot$ Heterogeneity $\cdot$ Biogenic structure $\cdot$ Filograna implexa . Microhabitat

\section{Introduction}

It has long been recognised that biodiversity and species richness in general are higher in the tropics and decrease along a latitudinal gradient towards the poles (Fischer 1960; Rosenzweig 1995; Hawkins 2001). Across a range of spatial scales, and for a wide spectre

H. Haanes $(\bowtie)$

Centre for Conservation Biology, Department of Biology,

Norwegian University of Science and Technology, 7491 Trondheim, Norway

e-mail: hhaanaes@gmail.com

B. Gulliksen

Department of Arctic and Marine Biology, Faculty of Biosciences,

Fisheries and Economics, University of Troms $\emptyset, 9037$ Troms $\emptyset$, Norway 
of taxonomic groups, it has been documented that average species richness within a sampling area of a given size increase when moving from high to low latitudes (Stevens 1989; Gaston 1996, 2000; Witman et al. 2004). Many hypotheses have been put forward to explain the observed patterns but few causal relationships have been identified (Pianka 1966; Gaston 2000; Hillebrand 2004; Jablonski et al. 2006; Harrison and Cornell 2007; Buckley et al. 2010). These patterns also exist in the marine benthos (Sanders 1968; Roy et al. 1998; Gray 2001; Witman et al. 2004), with diversity culminating on tropical coral reefs. Exceptions are however found within some taxa (Hillebrand 2004; Krug et al. 2007) and at some high latitude biodiversity hotspots like those created by deep coldwater coral reefs (Jensen and Fredriksen 1992; Freiwald et al. 2004).

Generally, structural complexity provides shelter against predation and physical disturbance (Menge et al. 1983; Mattila 1995; Walters and Wethey 1996) and introduces additional habitats and higher species diversity (Menge and Sutherland 1976; Sebens 1991). Encrusting organisms with hard exoskeletons build secondary substrate and may increase substrate complexity with crevices and cavities (Dean 1981; Senn and Glasstetter 1989; Sebens 1991). A species rich and diverse fauna is thus often associated with aggregated calcareous-building species and non-tropical shallow-water examples are found in aggregations of red algae (Sneli 1968; Salas and Hergueta 1986; Sintes 1987; Sintes et al. 1987) and serpulid polychaetes (Haines and Maurer 1980a, b; Kirkwood and Burton 1988; Moore et al. 1998). Especially in canals and tidal inlets with high current velocities, reef-like structures of encrusting animals may develop (Odum et al. 1974).

Serpulid polychaetes cement their tubes to firm substrates and occur throughout the world, often aggregating in unstable environments. Their growth is fast and some species can develop reefs that are several meters thick and kilometres long (ten Hove 1979), which provide habitats, feeding grounds, refuge, and reproduction areas for an abundant and diverse fauna (Moore et al. 1998). The genus Filograna is widely distributed, but due to the smallness of the tubes their aggregations are not spectacular (ten Hove 1979). Unlike most other genera, Filograna aggregations grow by asexual budding (Faulkner 1930; Kupriyanova and Jirkov 1997), possibly in addition to larval gregariousness, at a pace that on settlement panels can reach 4500 individuals per month (ten Hove 1979).

In this study we assess and characterise a very species rich and diverse fauna found living within aggregations of the polychaete Filograna implexa Berkeley, 1828 attached to an old shipwreck in a high-latitude tidal stream $\left(69^{\circ} \mathrm{N}\right)$.

\section{Area and substrate description}

The tidal stream "Rystraumen" is situated at $69^{\circ} \mathrm{N}$ in northern Norway (Fig. 1) and has current velocities that exceed four m/s (Sjøkartverk 1957; McClimans 1977). It is only 500 meters wide at the most narrow and has a sill depth of 35 meters. It connects two deep fjords (Balsfjorden and Malangen), which both have high annual primary production and large stocks of zooplankton (Gaarder 1938; Eilertsen and Taasen 1984; Tande 1990). Large volumes of homogenised water flow back and forth each tidal cycle (McClimans 1977; Svendsen 1995) and the exchange of dispersing larva, phyto- and zoo-plankton between the two fjords is probably important all through the productive season from late March through June (Reigstad and Wassmann 1996; Reigstad 2000). Food and recruitment is thus unlimited for benthic animals.

The M/S Flint (wrecked 1926) is situated $50 \mathrm{~m}$ from land and offers vertical hard substrate from 17 to $36 \mathrm{~m}$ depth. Kelp forest extends down to the upper parts $(<18 \mathrm{~m})$ and 


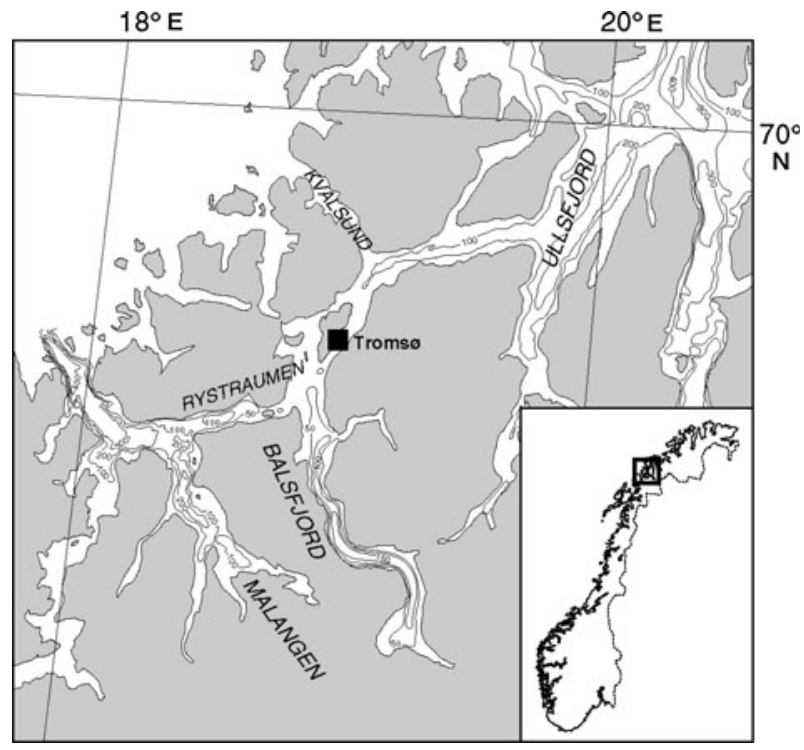

Fig. 1 Map showing the tidal inlet Rystraumen and adjacent waters of Troms $\varnothing$, northern Norway (redrawn from Reigstad 2000)

a dense sessile fauna covers most of the wreck. The hull is mostly intact and lays in the direction of the stream (W/E) in an upright position. The lack of a deck makes it open to predators. Water currents are much slower along the inside of the hull but $F$. implexa aggregations grow densely on both the inside and outside of vertical surfaces. Aggregations are also found on rocky substrata elsewhere in the Rystraumen and in other local tidal streams (Kvalsund, the entrance of Ullsfjord, Fig. 1) but are less common here compared to on the surface of wreck. The aggregations attain sizes from a few centimetres wide to continuous patches up to a meter long and comprise many levels of structural heterogeneity. The tubes form a lattice (Kupriyanova and Jirkov 1997) and run parallel adhering together to form ridges and protuberances (Knight-Jones and Moyse 1961). Crevices and holes in the lattice range in size from millimetres between single tubes to centimetres between protuberances (Fig. 2), and within the whole scale of structural levels animals are found.

\section{Methods and materials}

Eight aggregations of Filograna implexa were sampled from verticals beneath the rail on the wreck "M/S Flint" within a range of 19-24 m depth in the tidal stream "Rystraumen" during four SCUBA dives in spring. The aggregations were pinched off after two plastic bags had been put around each of them to ensure that none of the associated fauna escaped before or after sampling. After the dive each aggregation (still in plastic bags) was put in a separate plastic container and transported back to the laboratory. The volume of each aggregation was measured in litres (l) from the water expelled at submersion (Jensen and Fredriksen 1992), and animals that escaped through the plastic bags during transport were retained on a sieve with a $1.0 \mathrm{~mm}$ mesh. 


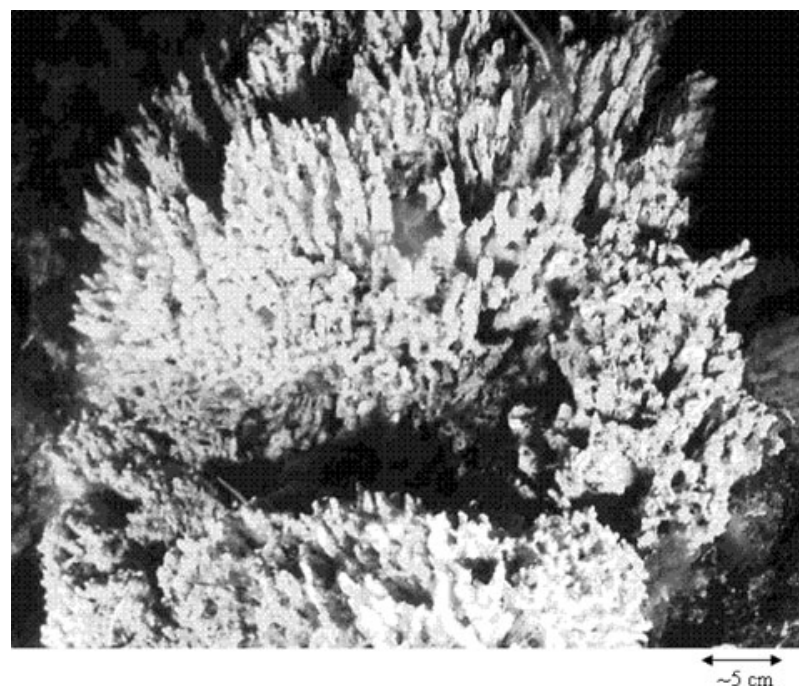

Fig. 2 Filograna implexa Berkeley, 1828 aggregate on the wreck of "M/S Flint" in the tidal stream Rystraumen, North Norway. The picture is approximately $1 / 3$ of natural size. An approximately $5 \mathrm{~cm}$ scale is shown on the picture. The aggregate shows two levels of structure scale; (1) millimetres among single tubes entwined into the finger-like projections and (2) centimetres among the finger-like projections

Obtaining the associated fauna of aggregations was problematic as animals were easily destroyed when the brittle aggregations were dismantled. Hydrochloric acid has been used by others to dissolve calcareous aggregations (Haines and Maurer 1980a) but was found to destroy the specimens, making species-identification difficult. We instead initiated an escape of the animals from within the aggregations by creating anoxic conditions in buckets with a lid for 24 to $48 \mathrm{~h}$, following an assumption that $\mathrm{O}_{2}$ first would be consumed within the aggregate and animals then would follow the $\mathrm{O}_{2}$ gradient out. Low temperatures $\left(4^{\circ} \mathrm{C}\right)$ in darkness gave the best result with most escaped animals compared to with room temperatures when animals died rather than escaping. Animals were retrieved from the bucket water on a sieve with $1.0 \mathrm{~mm}$ mesh, and preserved in $96 \%$ ethanol. The few animals remaining inside were obtained by dismantling the aggregations tube by tube, using tweezers and a magnifier glass (2x). Cryptic sponges of the class Demospongia were obtained by dissolving the Filograna lattice by weak hydrochloric acid. All specimens were afterwards donated to the Zoological Department of Troms $\varnothing$ University Museum.

The aggregations were identified as of the species-complex Filograna/Salmacina according to Kupriyanova and Jirkov (1997), but as Faulkner (1930) we observed both operculate and non-operculate specimens. We do not wish to participate in the debate on classification and call the specimens at hand Filograna implexa Berkeley, 1828. Specimens of the associated fauna of interest were classified to the lowest possible taxon. In the genera Musculus (Mollusca) and Myxilla (Porifera), the family Syllidae (Polychaeta), and the phyla Platyhelminthes and Nemertea, specimens were recognised as separate species and numbered. The Syllidae sp. 1 had a varying morphology and may constitute more than just one species. Juvenile specimens were included with adults if identifiable or treated separately, as with Musculus spp. (j). In the family Terebellidae (Polychaeta), juveniles were classified as Thelepus cincinnatus, which is a very common Terebellid in these waters (Brattegard and Holthe 1997), on the basis of a similar bristle configuration and body 
shape. Tube-building serpulids were not recorded quantitatively due to their high similarity to Filograna tubes, and were in addition to fragments and decaying specimens omitted from the analyses. All identified specimens were cross-checked with a catalogue of both published and unpublished records in Norwegian waters (Brattegard and Holthe 1997).

Individuals of solitary specimens were counted (anterior parts) and the biomass of all species weighed (wet). Biomass was included to avoid having to estimate the numbers of individuals in colonial species, and for comparison of solitary and colonial species distributions. The fauna was characterised by total species richness, solitary species richness, individual numbers (solitary species) and biomass (all species). Shannon-Wiener diversity indices were calculated from both the biomass composition of all species and from the abundance composition of solitary species using the function $H^{\prime}=\Sigma\left(\mathrm{p}_{\mathrm{i}} \times\left(\log _{2} \mathrm{p}_{\mathrm{i}}\right)\right)$ where $p_{i}$ is the proportion of the $i$ 'th species of the total sample (Krebs 1989).

Relationships of the above parameters with aggregation volume were investigated through regression. Since space often is limiting on hard substrate and new additional space colonised immediately (Jackson 1977), linear trend lines intersecting the origin were used for individual numbers and biomass, which were believed to increase continuously with the additional substrate and cavities provided by larger aggregations. Habitat number is not expected to increase continuously with additional substrate and cavities but rather reach a maximum involving a certain amount of associated species, and geometric trend lines were therefore used for solitary and total species richness regression against aggregation volume.

\section{Results}

In totally 4.41 of Filograna implexa aggregations $(n=8)$ we identified 61 solitary species (4663 individuals) and 38 colonial species that weighed $160.3 \mathrm{~g}$ together (Table 2). However, many different crustacean specimens were not identified to the species level but rather merged in congregated taxonomic groups (Caprellida, Gammaridea, Isopoda; Table 1, Appendix Table 2), and the total species number was therefore even higher. The Filograna aggregations protruded approximately $10 \mathrm{~cm}$ from the substrate and covered in total less than $0.05 \mathrm{~m}^{2}$. The observed species richness is therefore very high. There were few predominating species. On average, only 16 species were represented by more than three individuals, and eight species with more than $0.5 \mathrm{~g}$ of biomass per aggregation. This reflects the very high biodiversity within the small aggregations. Only the congregated taxon Gammaridea spp. was present with more than 100 individuals on average per aggregation (Table 1), but these represented many species. The average Filograna aggregate volume was $0.551(\mathrm{SE}=0.14)$, the Shannon-Wiener diversities 2.8 (abundance, $\mathrm{SE}=0.29$ ) and 2.7 (biomass, $\mathrm{SE}=0.27$ ), the solitary species number 30.4 $(\mathrm{SE}=4.0)$, the total species number $46.9(\mathrm{SE}=5.6)$, the individual number 582.9 $(\mathrm{SE}=263.1)$, and the biomass $20.04 \mathrm{~g}(\mathrm{SE}=5.1)$ per aggregation. Shannon-Wiener indices varied from low (1.3) to high (3.5), demonstrating from skew to even distributions of species.

The number of individuals (solitary), the biomass, the solitary and total species richness all increased with aggregation volume (Fig. 3). However, the relation of biomass was less linear due to a dominance of the sponge (Myxilla sp. 1) in the second largest aggregation and a comparably low biomass in the largest aggregation where animals were of a small size. Interestingly, both the solitary and total species numbers increased geometrically in relation to aggregation volume. 
Table 1 Common species in the fauna associated with aggregates $(n=8)$ of Filograna implexa Berkeley, 1828, from the wreck of "M/S Flint" in the tidal stream Rystraumen, northern Norway in spring 1998
Species regarded as common are those (of the 61 solitary species) occurring with means $>3$ individuals per aggregate and/or those (of the totally $99 \mathrm{sp}$.) with biomass means $>0.5 \mathrm{~g}$ biomass per aggregate (a) Abundance (solitary individuals)

\begin{tabular}{lcc}
\hline Species & Mean & SE \\
\hline Gammaridea spp. & 380.0 & 230.1 \\
Syllidae sp.1 & 48.88 & 18.57 \\
Isopoda spp. & 17.25 & 5.31 \\
Ophiopholis aculeata & 15.13 & 3.83 \\
Hiatella arctica & 13.25 & 6.96 \\
Caprellida spp. & 11.63 & 4.13 \\
Nematoda sp. & 11.50 & 6.07 \\
Musculus spp. (juv.) & 7.38 & 2.76 \\
Thelepus cincinnatus & 5.75 & 1.77 \\
Boltenia echinata & 5.13 & 1.90 \\
Syllidae sp.2 & 4.25 & 1.92 \\
Terebellomorpha indet. & 4.00 & 1.13 \\
Polynoidae indet & 3.25 & 1.46 \\
Actinaria spp. & 3.13 & 0.93 \\
Eulalia viridis & 3.13 & 1.23 \\
Polydontidae indet. & 3.13 & 1.76 \\
\hline
\end{tabular}

(b) Biomass (grams wet weight)

\begin{tabular}{lll}
\hline Species & Mean & SE \\
\hline Ophiopholis aculeata & 7.46 & 1.67 \\
Myxilla sp.1 & 1.77 & 1.69 \\
Thelepus cincinnatus & 1.45 & 0.45 \\
Halichondria sp. & 1.17 & 0.75 \\
Gammaridea spp. & 1.01 & 0.55 \\
Hyas araneus & 0.98 & 0.62 \\
Lophaster furcifer & 0.72 & 0.48 \\
Hiatella arctica & 0.71 & 0.39 \\
\hline
\end{tabular}

\section{Discussion}

This study identifies and characterises a very high local species richness and biodiversity at high latitude $\left(69^{\circ} \mathrm{N}\right)$. More than 100 species comprising only $160 \mathrm{~g}$ of biomass were found within only a 4.41 volume of Serpulid polychate aggregations. In general, average species richness decrease with latitude from the tropics across a range of spatial scales (Stevens 1989; Gaston 1996, 2000). Witman et al. (2004) demonstrated that also local species richness in the marine epibenthos follows this pattern and provided for various latitudes measures of small-scale species richness $\left(0.25 \mathrm{~m}^{2}\right)$. By comparison, the dense and diverse fauna found within Filograna aggregations covering less than $0.05 \mathrm{~m}^{2}$ represents a local high-latitude biodiversity hotspot that provides an exception to the latitudinal diversity gradient. Other exceptions to the pattern have been reported at various scales by the highlatitude biodiversity hotspots provided by the faunas associated with deep coldwater coral reefs (Jensen and Fredriksen 1992; Freiwald et al. 2004) and other shallow-water Serpulid 
polychaete aggregations (Haines and Maurer 1980a, b; Kirkwood and Burton 1988; Moore et al. 1998).

A high fauna density may be sustained in the Filograna aggregations by the abundant supply of food particles passing through the tidal inlet from adjacent productive waters each tidal cycle. The increase of fauna density and biomass with aggregation size indicates that colonisation is related to the available surface area provided by aggregation growth (Fig. 3). High benthic densities are also found at high latitudes in tidal inlets in North American waters, but have lower species richness (Odum et al. 1974). The fauna inside the Filograna aggregations is very species rich compared to corresponding faunas associated with less heterogeneous biogenic structures. In aggregated clumps of the algae Lithothamnion situated in Norwegian waters with similar currents, a medium-dense and less species rich fauna (55 species, 2593 individuals in 1-1.5 $\mathrm{m}^{2}$ ) has been found (Sneli 1968). The Filograna aggregations have a much finer structure with numerous tiny tubes in irregular spatial patterns (Knight-Jones and Moyse 1961; Kupriyanova and Jirkov 1997) and the greater heterogeneity probably offers a higher diversity of microhabitats. Different

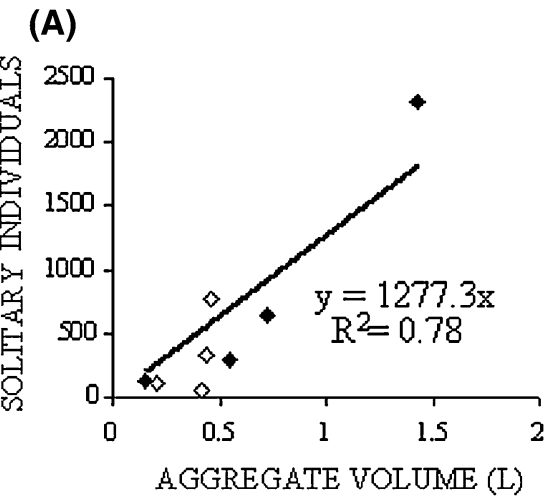

(C)

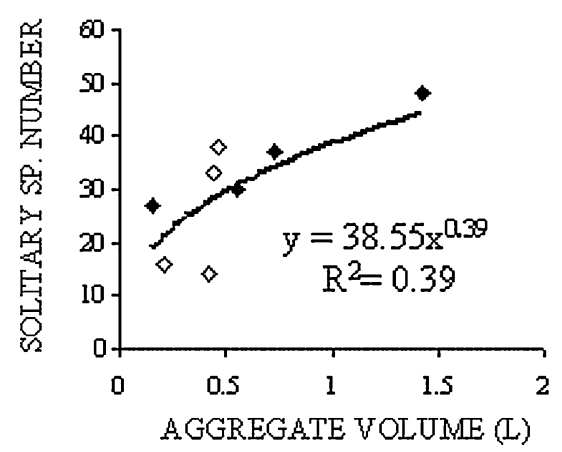

(B)

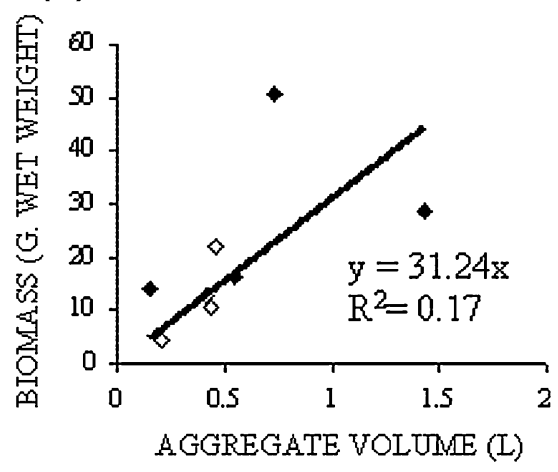

(D)

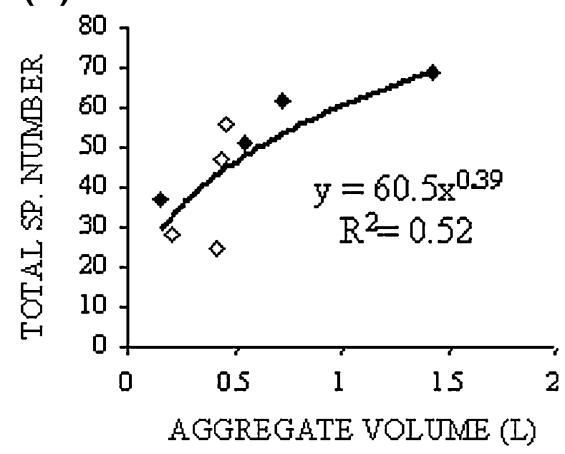

\section{Outside aggregates Inside aggregates}

Fig. 3 Relationships between variables of associated faunas and the volume (1) of Filograna implexa Berkeley, 1828, aggregates $(n=8)$ from the wreck "M/S Flint" in the tidal stream "Rystraumen" in the northern Norway. Regression equations and coefficients of determination $\left(R^{2}\right)$ are given for the linear trend lines of individual numbers of solitary species (a) and biomass of all species (b), and for the geometric trend lines of solitary species richness (c) and total species richness (d) 
species were thus found in variously sized holes and crevices of the Filograna aggregations.

Increased microhabitat diversity with increased physical structure is probably the most universal and important of the processes enhancing diversity, especially where biogenic structures or the substratum provide more complexity and attachment sites (Sebens 1991). Structures built by sessile animals increase colonisation of other sessile and motile organisms (Dean 1981; Bros 1987) and aggregated or colonial species decelerate passing water into low, intermediate and strong turbulent flow (Okamura 1984; Sebens et al. 1997) so that microhabitat numbers increase (Sebens 1991). The great heterogeneity of Filograna aggregations probably decelerates water into a variety of water velocities suitable for species with different optimal foraging velocities. This may explain the high recorded number of different filter feeders, ranging from quite passive (e.g. poriferans, bryozoans, hydrozoans) to active, pumping water with a muscle apparatus (e.g. bivalves, some ascidians). It is also characteristic that the organism with the highest biomass (the echinoderm Ophiopholis aculeata) can live with the central disc protected within the aggregates but with the filter-feeding arms emerging out into the water passing by. The increase of habitat diversity with heterogeneity is supported by the increase of species richness with increasing size of Filograna aggregations (Fig. 3), suggesting that new tubes and aggregation growth forming new holes, crevices and ridges involve not just more space for additional individuals but also new microhabitats for new species. Similar increases in species number with the size of biogenic structures are also reported for aggregations of another serpulid at deeper waters (Kaiser et al. 1999) and a deep-water coral (Jensen and Fredriksen 1992). A further increase in microhabitat diversity can be created by species all ready present, as these may involve the coexistence of several new species (Sebens 1991). Within the Filograna aggregations both detritivores, scavengers and carnivores were thus present (Table 1 and see Appendix Table 2).

Another effect that probably increases the diversity of the fauna inside Filograna aggregations is their exclusion of predators. Rigid structural complexity above a certain threshold lowers predation rates (Coull and Wells 1983; Walters 1992), and is probably the second most universal process enhancing diversity, especially when predators are large and possibly generalised in their diet (Sebens 1991). Filograna aggregations provide refuge against large predators like the sea urchin Strongylocentrotus droebachiensis, which is regarded a key species in nearby areas (Gulliksen and Sandnes 1980), adult fish, crabs (Hyas araneus), and starfish (e.g. Asterias rubens). However, micro-predators like gammarids, caprellids, and certain polychaetes (e.g. Syllidae spp., Eulalia viridis, Nereis pelagica) were found inside aggregations and may limit the aggregation fauna diversity.

Wrecks also provide structural complexity and function as artificial reefs (Bohnsack 1991; Bohnsack et al. 1997; Bortone 1998) and their attached fauna is reported to increase in density and diversity with current exposure and lowered sedimentation (Baynes and Szmant 1989). However, these factors together with the slope of the substrate are more important than substrate type in distinguishing wreck faunas from natural substrata (Gabriele et al. 1999) and succession on wrecks seems to follow a classical pattern (Warner 1985; Dipper 1991).

We conclude that also at high latitudes, heterogeneity introduced by biogenic structures may increase species richness and biodiversity. The observed species richness and biodiversity was very high compared to the high latitude and small sample sizes, and represent local biodiversity hotspots that provide exceptions to the latitudinal diversity gradient. Comparison with other studies and the relationship between species number and aggregation size in this study suggest that spatial heterogeneity is the main reason for the 
elevated diversity at such biodiversity hotspots associated with biogenic structures. Such structures should therefore be mapped and conserved for an optimal management.

Acknowledgments We thank the crew of the "M/S Hyas" for assistance during cruises. For good help and assistance during diving we thank dive master Bjørnar Seim, Jonas Henriksen, Bjørn Kraft and Robert Johansen. For financial support we would like to thank the Amundsen Senteret at the University of Troms $\varnothing$, Solofondet, Lise og Arnfinn Hejes Fond and Stiftelsen Thomas Fearnley, Heddy og Nils Astrup.

Open Access This article is distributed under the terms of the Creative Commons Attribution Noncommercial License which permits any noncommercial use, distribution, and reproduction in any medium, provided the original author(s) and source are credited.

\section{Appendix}

Table 2 The species of the fauna associated with aggregates of Filograna implexa Berkeley, 1828, sampled from the wreck of "M/S Flint" in the tidal stream Rystraumen, North Norway the spring of 1998

\begin{tabular}{|c|c|c|c|c|}
\hline \multirow[t]{2}{*}{ Species } & \multicolumn{2}{|c|}{$\begin{array}{l}\text { Abundance (solitary } \\
\text { individuals) }\end{array}$} & \multicolumn{2}{|c|}{$\begin{array}{l}\text { Biomass (grams wet } \\
\text { weight) }\end{array}$} \\
\hline & Mean & SE & Mean & SE \\
\hline \multicolumn{5}{|l|}{ Porifera } \\
\hline Chlatrina coriacea (Montagu, 1812) & & & 0.01 & 0.01 \\
\hline Leucosolenia sp. & & & 0.01 & 0.01 \\
\hline Grantia compressa (Fabricius, 1780) & & & 0.15 & 0.09 \\
\hline Scypha ciliata (Fabricius, 1780) & & & 0.11 & 0.05 \\
\hline Adociidae indet. & & & 0.04 & 0.04 \\
\hline Halichondria sp. & & & 1.17 & 0.75 \\
\hline Haleciidae indet. & & & 0.01 & 0.01 \\
\hline Hymedesmia sp. & & & 0.32 & 0.16 \\
\hline Mycale sp. & & & 0.29 & 0.16 \\
\hline Myxilla sp.1 & & & 1.77 & 1.69 \\
\hline Myxilla sp.2 & & & 0.01 & 0.01 \\
\hline \multicolumn{5}{|l|}{ Cnidaria } \\
\hline Actinaria spp. (j) & 3.13 & 0.93 & 0.11 & 0.06 \\
\hline Calycella syringa $(\mathrm{L} ., 1767)$ & & & 0.01 & 0.01 \\
\hline Eudendrium ramosum (L., 1758) & & & 0.01 & 0.01 \\
\hline Lafoea dumosa (Fleming, 1828) & & & 0.01 & 0.01 \\
\hline Serturella polyzonias (L., 1758) & & & 0.06 & 0.05 \\
\hline Tubularia larynx Ellis \& Solander, 1786 & & & 0.19 & 0.19 \\
\hline Hydroida indet. & & & 0.01 & 0.01 \\
\hline \multicolumn{5}{|l|}{ Platyhelminthes } \\
\hline Platyhelminthes sp.1 & 2.13 & 0.67 & 0.01 & 0.01 \\
\hline Platyhelminthes sp.2 & 0.38 & 0.26 & 0.05 & 0.03 \\
\hline \multicolumn{5}{|l|}{ Nematoda } \\
\hline Nematoda sp. & 11.50 & 6.07 & 0.01 & 0.01 \\
\hline
\end{tabular}


Table 2 continued

\begin{tabular}{|c|c|c|c|c|}
\hline \multirow[t]{2}{*}{ Species } & \multicolumn{2}{|c|}{$\begin{array}{l}\text { Abundance (solitary } \\
\text { individuals) }\end{array}$} & \multicolumn{2}{|c|}{$\begin{array}{l}\text { Biomass (grams we } \\
\text { weight) }\end{array}$} \\
\hline & Mean & SE & Mean & SE \\
\hline \multicolumn{5}{|l|}{ Nemertea } \\
\hline Nemertea sp.1 & 1.38 & 0.86 & 0.01 & 0.01 \\
\hline Lineus ruber (O.F.Müller, 1774) & 1.38 & 0.52 & 0.14 & 0.06 \\
\hline \multicolumn{5}{|l|}{ Mollusca } \\
\hline Ophistobranchia indet. & 0.38 & 0.18 & 0.01 & 0.01 \\
\hline Colus gracilis (da Costa, 1778) (j) & 2.88 & 2.20 & 0.08 & 0.05 \\
\hline Heteranomia squamula (L., 1758) (j) & 1.50 & 0.76 & 0.05 & 0.02 \\
\hline Modiolus modiolus (L., 1758) (j) & 1.50 & 0.96 & 0.03 & 0.03 \\
\hline Musculus sp.1 (*) & 1.38 & 0.84 & 0.28 & 0.21 \\
\hline Musculus sp.2 & 0.50 & 0.38 & 0.02 & 0.01 \\
\hline Musculus spp. (j) & 7.38 & 2.76 & 0.01 & 0.01 \\
\hline Chlamys islandica (Müller, 1776) (j) & 0.75 & 0.75 & 0.01 & 0.01 \\
\hline Hiatella arctica (L., 1758) (j) & 13.25 & 6.96 & 0.71 & 0.39 \\
\hline \multicolumn{5}{|l|}{ Annelida } \\
\hline Polychaeta indet. & 0.5 & 0.27 & 0.01 & 0.01 \\
\hline Terebellomorpha indet. (j) & 4 & 1.13 & 0.05 & 0.03 \\
\hline Cirratulus cirratulus (O.F.Müller, 1776) & 0.5 & 0.5 & 0.01 & 0.01 \\
\hline Nereididae indet. & 0.25 & 0.25 & 0.01 & 0.01 \\
\hline Nereis pelagica $(\mathrm{L} ., 1758)$ & 1.75 & 0.90 & 0.21 & 0.12 \\
\hline Eulalia viridis (L., 1767) & 3.13 & 1.23 & 0.03 & 0.01 \\
\hline Polydontidae spp. & 3.13 & 1.76 & 0.02 & 0.01 \\
\hline Polynoidae spp. & 3.25 & 1.46 & 0.28 & 0.11 \\
\hline Myxicola infundibulum (Renier, 1804) & 0.63 & 0.63 & 0.01 & 0.01 \\
\hline Pseudopotamilla sp. & 2.75 & 1.37 & 0.02 & 0.01 \\
\hline Sabellidae indet. & 0.38 & 0.26 & 0.01 & 0.01 \\
\hline Sabella penicillus (L., 1767) & 0.13 & 0.13 & 0.03 & 0.03 \\
\hline Serpulidae indet. & 0.13 & 0.13 & 0.01 & 0.01 \\
\hline Chitinopoma sp. & 0.75 & 0.49 & 0.01 & 0.01 \\
\hline Filograna implexa Berkeley, 1828 & \multicolumn{4}{|c|}{ Not recorded } \\
\hline Hydroides norvegica Gunnerus, 1768 & 0.88 & 0.44 & 0.03 & 0.02 \\
\hline Pomatoceros triqueter (L., 1767) & 2.75 & 1.16 & 0.06 & 0.03 \\
\hline Sigalionidae sp. & 0.38 & 0.26 & 0.01 & 0.01 \\
\hline Jugaria granulata (L., 1767) & 2.25 & 1.37 & 0.01 & 0.01 \\
\hline Syllidae indet. & 0.38 & 0.38 & 0.01 & 0.01 \\
\hline Syllidae sp.1 (*) & 48.88 & 18.57 & 0.12 & 0.05 \\
\hline Syllidae sp.2(*) & 4.25 & 1.92 & 0.02 & 0.01 \\
\hline Syllidae sp.3 (*) & 0.38 & 0.18 & 0.01 & 0.01 \\
\hline Proceraea sp. & 0.5 & 0.38 & 0.01 & 0.01 \\
\hline Polycirrus sp. & 0.13 & 0.13 & 0.01 & 0.01 \\
\hline Thelepus cincinnatus (O.Fabricius, 1780) $(*)$ & 5.75 & 1.77 & 1.46 & 0.45 \\
\hline
\end{tabular}


Table 2 continued

\begin{tabular}{|c|c|c|c|c|}
\hline \multirow[t]{2}{*}{ Species } & \multicolumn{2}{|c|}{$\begin{array}{l}\text { Abundance (solitary } \\
\text { individuals) }\end{array}$} & \multicolumn{2}{|c|}{$\begin{array}{l}\text { Biomass (grams wet } \\
\text { weight) }\end{array}$} \\
\hline & Mean & SE & Mean & SE \\
\hline \multicolumn{5}{|l|}{ Crustacea } \\
\hline Chirona hammeri (Ascanius, 1767) (j) & 2 & 1.12 & 0.19 & 0.11 \\
\hline Verrucia stroemi (O.F.Müller, 1776) (*) & 0.88 & 0.52 & 0.01 & 0.01 \\
\hline Caprellida spp. & 11.63 & 4.13 & 0.08 & 0.03 \\
\hline Gammaridea spp. & 380 & 230.1 & 1.01 & 0.55 \\
\hline Hyas araneus (L., 1758) (j) & 0.63 & 0.18 & 0.98 & 0.62 \\
\hline Thoralus chranchii (Leach, 1817) & 0.13 & 0.13 & 0.01 & 0.01 \\
\hline Isopoda spp. & 17.25 & 5.31 & 0.05 & 0.02 \\
\hline \multicolumn{5}{|l|}{ Pycnogonida } \\
\hline Pycnogonida sp.1 & 1.88 & 1.19 & 0.01 & 0.01 \\
\hline \multicolumn{5}{|l|}{ Bryozoa } \\
\hline Crisella producta (Smitt, 1865) & & & 0.01 & 0.01 \\
\hline Crisia eburnea (L., 1758) & & & 0.01 & 0.01 \\
\hline Crisia sp. & & & 0.01 & 0.01 \\
\hline Crisia klugei Ryland, 1967 & & & 0.01 & 0.01 \\
\hline Filicrisia sp. & & & 0.01 & 0.01 \\
\hline Diplosolen obelia (Johnston, 1838) & & & 0.02 & 0.01 \\
\hline Lichenopora verrucia (O.Fabricius, 1780) & & & 0.01 & 0.01 \\
\hline Lichenoporidae indet. & & & 0.01 & 0.01 \\
\hline Oncousoecia sp. & & & 0.02 & 0.02 \\
\hline Idmidronea atlantica (Forbes, in Johnston, 1847) & & & 0.01 & 0.01 \\
\hline Tubulipora lillicea (Pallas, 1776) & & & 0.01 & 0.01 \\
\hline Tubulipora penincillata (O.Fabricius, 1780) & & & 0.06 & 0.04 \\
\hline Tubuliporidae indet. & & & 0.01 & 0.01 \\
\hline Cheilostomata indet. & & & 0.01 & 0.01 \\
\hline Tricellaria ternata (Ellis \& Solander, 1786) & & & 0.34 & 0.20 \\
\hline \multicolumn{5}{|l|}{ Echinodermata } \\
\hline Lophaster furcifer (Düben \& Koren, 1846)(j) & 1.5 & 0.38 & 0.72 & 0.48 \\
\hline Strongylocentrotus droebachiensis (O.F.Müller, 1776) (j) & 0.13 & 0.13 & 0.01 & 0.01 \\
\hline Cucumaria frondosa (Gunnerus, 1770) (j) & 0.75 & 0.31 & 0.34 & 0.25 \\
\hline Psolus sp. (*) & 1.88 & 0.90 & 0.01 & 0.01 \\
\hline Ekmania barthi (Troschel, 1846) (*) & 0.38 & 0.26 & 0.01 & 0.01 \\
\hline Ophiopholis aculeata (L., 1767) (*) & 15.13 & 3.83 & 7.46 & 1.67 \\
\hline Ophiotrix fragilis (Abildgaard, 1789) & 0.38 & 0.26 & 0.09 & 0.09 \\
\hline \multicolumn{5}{|l|}{ Chordata } \\
\hline Ascidiacea indet. $(*)$ & 0.38 & 0.26 & 0.01 & 0.01 \\
\hline Ascidia $\mathrm{sp} .(\mathrm{j})$ & 1.88 & 0.95 & 0.01 & 0.01 \\
\hline Ascidia callosa Stimpson, $1852(*)$ & 1.25 & 0.45 & 0.06 & 0.02 \\
\hline Ascidia obliqua Alder, 1863 (*) & 0.88 & 0.48 & 0.01 & 0.01 \\
\hline Didemnum sp. & & & 0.10 & 0.06 \\
\hline Molgula sp. (*) & 1.75 & 0.82 & 0.02 & 0.01 \\
\hline
\end{tabular}


Table 2 continued

\begin{tabular}{|c|c|c|c|c|}
\hline \multirow[t]{2}{*}{ Species } & \multicolumn{2}{|c|}{$\begin{array}{l}\text { Abundance (solitary } \\
\text { individuals) }\end{array}$} & \multicolumn{2}{|c|}{$\begin{array}{l}\text { Biomass (grams wet } \\
\text { weight) }\end{array}$} \\
\hline & Mean & SE & Mean & SE \\
\hline Aplidium glabrum (Verrill, 1871) (*) & & & 0.24 & 0.20 \\
\hline Aplidium sp. (*) & & & 0.01 & 0.01 \\
\hline Aplidium pallium (Verrill, 1871) (*) & & & 0.02 & 0.02 \\
\hline Synoicum sp. (j) & & & 0.01 & 0.01 \\
\hline Boltenia echinata (L., 1767) (j) & 5.13 & 1.90 & 0.16 & 0.11 \\
\hline \multicolumn{5}{|l|}{ Plant kingdom } \\
\hline Fucus eggs & & & 0.01 & 0.01 \\
\hline
\end{tabular}

Species classified by phyla, class or order, and family, and aggregate means and standard errors of abundance (solitary species) and biomass (wet weight) are presented non-standardised. Weights less than $0.01 \mathrm{~g}$ are denoted 0.01 because alcohol wet weight not gave precise measures. Not present species are presented as blanks, as are abundance data of colonial species

(*) Taxa represented also by juveniles

(j) Taxa represented mostly by juveniles

\section{References}

Baynes TW, Szmant AM (1989) Effect of current on the sessile benthic community structure of an artificial reef. Bull Mar Sci 44:545-566

Bohnsack JA (1991) Habitat structure and the design of artificial reefs. In: Bell SS, McCoy ED, Mushinsky HR (eds) Habitat structure: the physical arrangement of objects in space. Chapman and Hall, London

Bohnsack JA, Eklund AM, Szmant AM (1997) Artificial reef research: is there more than the attractionproduction issue? Fisheries 22:14-16

Bortone SA (1998) Resolving the attraction-production dilemma in artificial reef research: some yeas and nays. Fisheries 23:6-10

Brattegard T, Holthe T (1997) Distribution of marine, benthic macro-organisms in Norway. Research report for DN 1997-1. Directorate for Nature Managment

Bros WE (1987) Effects of removing or adding structure (Barnacle Shells) on recruitment to a fouling community in Tampa-Bay, Florida. J Exp Mar Biol Ecol 105:275-296

Buckley LB et al (2010) Phylogeny, niche conservatism and the latitudinal diversity gradient in mammals. Proc Royal Soc B 277:2131-2138

Coull BC, Wells JBC (1983) Refuges from fish predation: experiments with phytal meiofauna from the New Zealand rocky intertidal. Ecology 64:1599-1609

Dean T (1981) Structural aspects of sessile invertebrates as organizing forces in an estuarine fouling community. J Exp Mar Biol Ecol 53:163-180

Dipper F (1991) Colonisation and natural changes in a newly established 'artificial reef' in Gulf waters. In: Elliott M, Ducrotoy J-P (eds) Estuaries and coasts: spatial and temporal intercomparisons. Olsen and Olsen, University of Caen

Eilertsen HC, Taasen JP (1984) Investigations on the plankton community of Balsfjorden, northern Norway. The phytoplankton 1976-1978. Environmental factors, dynamics of growth, and primary production. Sarsia 69:1-15

Faulkner GH (1930) The anatomy and the histology of bud-formation in the Serpulid Filograna implexa, together with some cytological observations on the nuclei of the neoblasts. J Linn Soc (Zool) XXXVII:109-191

Fischer AG (1960) Latitudinal variations in organic diversity. Evolution 14:64-81

Freiwald A et al (2004) Cold-water coral reefs. UNEP-WCMC, Cambridge

Gaarder KR (1938) Phytoplankton studies from the Troms $\varnothing$ district 1930-1931. Yearbooks of Troms $\emptyset$ Museum 55:1-159 
Gabriele M et al (1999) Sublittoral hard substrate communities of the northern Adriatic Sea. Cah Biol Mar 40:65-76

Gaston KJ (1996) Biodiversity—latitudinal gradients. Prog Phys Geogr 20:466-476

Gaston KJ (2000) Global patterns in biodiversity. Nature 405:220-227

Gray JS (2001) Marine diversity: the paradigms in patterns of species richness examined. Sci Mar 65:41-56

Gulliksen B, Sandnes O (1980) Marine bunndyrsamfunn, "nøkkelarter” og felteksperimenter på hardbunn (In Norwegian). Fauna 33:1-9

Haines JL, Maurer D (1980a) Quantitative faunal associates of the Serpulid polychaete Hydroides dianthus. Mar Biol 56:43-47

Haines JL, Maurer D (1980b) Benthic invertebrates associated with a Serpulid polychaete assemblage in a temperate estuary. Int Rev Ges Hydrobiol 65:643-656

Harrison S, Cornell HV (2007) Introduction: merging evolutionary and ecological approaches to understanding geographic gradients in species richness. Am Nat 170:S1-S4

Hawkins BA (2001) Ecology's oldest pattern? Trends Ecol Evol 16:470

Hillebrand $\mathrm{H}$ (2004) On the generality of the latitudinal diversity gradient. Am nat 163:192-211

Jablonski D, Roy K, Valentine JW (2006) Out of the tropics: evolutionary dynamics of the latitudinal diversity gradient. Science 314:102-106

Jackson JBC (1977) Habitat area, colonization, and development of epibenthic community structure. Pergamont, New York

Jensen A, Fredriksen R (1992) The fauna associated with the bank-forming deep-water coral Lopheliapertusa (Scleractinaria) on the Faroe Shelf. Sarsia 77:53-69

Kaiser MJ et al (1999) Fishing effects in northeast Atlantic shelf seas: patterns in fishing effort, diversity and community structure VII. The effects of trawling disturbance on the fauna associated with the tubeheads of serpulid worms. Fish Res 40:195-205

Kirkwood JM, Burton HR (1988) Macrobenthic species assemblages in Ellis Fjord, Vestfold Hills, Antarctica. Mar Biol 97:445-457

Knight-Jones EW, Moyse J (1961) Intraspecific competition in sedentary marine animals. Symposia of the Society for Experimental Biology. Cambridge University Press, Cambridge

Krebs CJ (1989) Ecological methology. Harper Collins, University of British Colombia

Krug AZ, Jablonski D, Valentine JW (2007) Contrarian clade confirms the ubiquity of spatial origination patterns in the production of latitudinal diversity gradients. Proc Natl Acad Sci 104:18129-18134

Kupriyanova EK, Jirkov IA (1997) Serpulidae (Annelida, Polychaeta) of the Arctic Ocean. Sarsia 82:203-236

Mattila J (1995) Does habitat complexity give refuge against fish predation? Some evidence from two field experiments. In: Smith CJ (ed) Biology and ecology of shallow coastal waters: Proceedings of the 28th European Marine Biology Symposium. Olsen and Olsen, Fredrikshaug

McClimans TA (1977) Measurements of swift tidal currents in the Troms $\emptyset$ area (in Norwegian). Vassdragsog Havnelaboratoriets Meddelelser 16E:47-68

Menge BA, Sutherland JP (1976) Species diversity gradients synthesis of the roles of predation competition and temporal heterogeneity. Am Nat 110:351-369

Menge BA, Ashkenas LR, Matson A (1983) Use of artificial holes in studying community development in cryptic marine habitats in a tropical rocky inter tidal region. Mar Biol 77:129-142

Moore CG, Saunders GR, Harries DB (1998) The status of reefs of Serpula vermicularis L. (Polychaeta: Serpulidae) in Scotland. Aquat Conserv 8:645-656

Odum HT, Copeland BJ, McMahan EA (1974) Coastal ecological systems of the United States. The Conservation Foundation, Washington, DC

Okamura B (1984) The effects of ambient flow velocity, colony size, and upstream colonies on the feeding success of Bryozoa. I. Bugula stolonifera Ryland, an arborescent species. J Exp Mar Biol Ecol 83:179-193

Pianka ER (1966) Latitudinal gradients in species diversity: a review of concepts. Am Nat 100:33-46

Reigstad M (2000) Plankton community and vertical flux of biogenic matter in north Norwegian fjords: regulating factors, temporal and spatial variations. Dissertation, Institute of Aquatic Research Environmental Biology, Norwegian College of Fishery Science, Troms $\emptyset$

Reigstad M, Wassmann P (1996) Importance of advection for pelagic-benthic coupling in north Norwegian fjords. Sarsia 80:245-257

Rosenzweig ML (1995) Species diversity in space and time. Cambridge University Press, Cambridge

Roy K et al (1998) Marine latitudinal diversity gradients: tests of causal hypotheses. Proc Natl Acad Sci 95:3699-3702

Salas C, Hergueta E (1986) The molluscan fauna of calcareous concretions of Mesophyllum lichenoides (Ellis) Lemoine. Study of annual cycle diversity. Iberus 6:57-65 
Sanders HL (1968) Marine benthic diversity: a comparative study. Am Nat 102:243-282

Sebens KP (1991) Habitat structure and community dynamics in marine benthic systems. In: Mushinsky HR (ed) Habitat structure: the physical arrangement of objects in space. Chapman and Hall, London

Sebens KP, Witting J, Helmuth B (1997) Effects of water flow and branch spacing on particle capture by the reef coral Madracis mirabilis (Duchassaing and Michelotti). J Exp Mar Biol Ecol 211:1-28

Senn DG, Glasstetter M (1989) On the occurrence of barnacle -reefs around Cocos-Island, Costa Rica. Senck Marit 20:241-249

Sintes DM (1987) La comunidad de Anélidos Poliquetos de las concreciones de algas calcáreas del litoral catalán. Caracterización de las espicies (In Spanish). Vol 13, Publicaciones del Departamento de Zoología, Universidad de Barcelona, pp 45-54

Sintes DM, Dantart L, Ballesteros M (1987) Moluscos de las concreciones de algas calceras del litoral Catalan (NE España; in Spanish). Lavori 23:445-456

Sjøkartverk N (1957) Den Norske Los (in Norwegian). Norges Sjøkartverk, Oslo, pp 37-44

Sneli J-A (1968) The Lithothamnion community in Nord-Möre, Norway. With notes on the epifauna of Desmarestia viridis (Müller). Sarsia 31:69-74

Stevens GC (1989) The latitudinal gradient in geographical range: How so many species coexist in the tropics. Am Nat 133:240-256

Svendsen H (1995) Physical oceanography of coupled fjord-coast systems in northern Norway with special focus on frontal dynamics and tides. In: Leinaas HP (ed) Proceedings from the Mare Nor Symposium on the Ecology of fjords and coastal waters. Elsevier Science, Amsterdam

Tande K (1990) Calanus in north Norwegian fjords and in the Barents Sea. In: Sakshaug E, Hopkins CCE, Oeritsland NA (eds) Pro Mare symposium on polar marine ecology. Norwegian Polar Institute Press, Trondheim

ten Hove HA (1979) Different causes of mass occurence in Serpulids. In: Rosen BR (ed) Biology and systematics of colonial organisms. Academic Press, London and New York

Walters LJ (1992) Postsettlement success of the Arborescent Bryozoan Bugula neritina (L) - the importance of structural complexity. J Exp Mar Biol Ecol 164:55-71

Walters LJ, Wethey DS (1996) Settlement and early post settlement survival of sessile marine invertebrates on topographically complex surfaces: The importance of refuge dimensions and adult morphology. Mar Ecol Prog Ser 137:161-171

Warner GF (1985) Dynamic stability in two contrasting epibenthic communities. In: Gibbs PE (ed) Proceedings of 19th European Marine Biology Symposium. Cambridge University Press, Cambridge

Witman JD, Etter RJ, Smith F (2004) The relationship between regional and local species diversity in marine benthic communities: a global perspective. Proc Natl Acad Sci 101:15664-15669 